\author{
Review Article \\ www.ijrap.net (ISSN:2229-3566)
}

\title{
REGIMENAL MODALITIES FOR THE MANAGEMENT OF CERVICAL SPONDYLOSIS \\ (WAJA' UR RAQABA): AN EVIDENCE-BASED COMPREHENSIVE REVIEW
}

Hina Kouser V ${ }^{1}$, Mohd Nayab ${ }^{2 *}$, Manzoor Ahmad Mir ${ }^{3}$, Mohd Anwar ${ }^{4}$, Jamal Akhtar ${ }^{5}$

${ }^{1}$ PG Scholar, Department of Ilaj bit Tadbeer, National Institute of Unani Medicine, Bengaluru, Karnataka, India

${ }^{2}$ Assistant Professor, Department of Ilaj bit Tadbeer, National Institute of Unani Medicine, Bengaluru, Karnataka, India

${ }^{3}$ PG Scholar, Department of Tahaffuzi wa Samaji Tib, National Institute of Unani Medicine, Bengaluru, Karnataka, India

${ }^{4}$ Professor and Chairman, Department of Ilaj bit Tadbeer, Ajmal Khan Tibbiya College, Aligarh Muslim University, Aligarh, UP, India

${ }^{5}$ Research Officer, Scientist Grade-III, Central Council for Research in Unani Medicine, New Delhi, India

Received on: 05/08/21 Accepted on: 15/09/21

\author{
*Corresponding author \\ E-mail: nayabdr@gmail.com
}

DOI: 10.7897/2277-4343.1205150

\begin{abstract}
Musculoskeletal conditions are the leading contributors to disability worldwide, typically characterized by pain, decreased mobility, dexterity, and functional ability. After back pain, neck pain is the most frequent musculoskeletal cause of consultation in primary care worldwide. Cervical spondylosis is a chronic degenerative process of the cervical spine characterized by pain in the neck, degenerative changes in the intervertebral disc, and osteophyte formation. This condition is known as waja'ur raqaba in the Unānī system of medicine. Its rate is 3.3 patients per 1000 people in the general population. Its increasing prevalence is drawing the attention of the medical fraternity. Due to the limited efficacy of conventional treatment and potential side effects of long-term use, patients seek alternative treatment options. Unāni physicians claimed the management of various joint disorders with the help of several tadābīr. The objective of this critical review is to address the claims of Unāni physicians and clinical studies conducted on the efficacy of various Regimenal modalities in the management of joint pain. Classical Unānī literature, peer-reviewed journal articles, and RCTs that predominantly focused on the use of Regimenal modalities in joint pain were included in this review. It was extracted that several Regimenal modalities are effective in the management of various joint disorders including cervical spondylosis. Despite the long history of the use of various Regimenal modalities in several painful conditions, more systematic, well designed, rigorous, randomized, controlled clinical trials are needed to determine which approaches have merit.
\end{abstract}

Keywords: 'Ilāj bit-tadbīr; dalk; hijāāma; cervical spondylosis; Unani Medicine

\section{INTRODUCTION}

Cervical spondylosis (sěr' vǐ - kăl + spǒn"dǐ-lō'š̌s) is derived from Latin words; Cervic means "neck", and Spondyl, osis means "vertebra condition"1. Cervical spondylosis is a chronic degenerative process of the cervical spine characterized by pain in the neck, degenerative changes in the intervertebral disc, and osteophyte formation ${ }^{2,3}$. After back pain, neck pain is the most frequent musculoskeletal cause of consultation in primary care worldwide 4 . About two-thirds of the population have neck pain at some time in their lives with an incidence of $10 \%$ at age 25 and $75 \%$ by the age of 65 and prevalence is highest in middle age ${ }^{4,5}$. The cervical spondylosis prevalence rate is 3.3 patients per 1000 people in the general population ${ }^{3}$. Cervical spondylosis usually occurs in middle-aged and elderly people 5 . According to the Global Burden of Disease (GBD) 2015, more than a third of a billion people worldwide had mechanical neck pain of at least 3 months duration, underscoring the global health implications of degenerative cervical spondylosis ${ }^{6}$.

Waja'ur Raqaba has not been described directly in classical Unānī text. Most of the eminent physicians have used a broad term waja'ul mafāsil to describe the joints pain and named them according to the site of pain like waja'ur rukaba (knee pain), waja'ul warik (ischial pain), 'irqun-nasa (sciatica), niqris (gout), etc. ${ }^{7-9}$. Similarly, when pain occurs in fiqrāt-i-unuq (cervical vertebrae), it is termed as waja'ur raqaba (cervical spondylosis).
The etiology of cervical spondylosis is poorly understood and usually multifactorial including poor posture, anxiety, advancement of age, occupational heavy loading, trauma, depression, neck strain, and sporting ${ }^{4}$. Age-related degenerative changes in the cervical spine are considered the primary cause of cervical spondylosis ${ }^{10}$. These changes include reduction in one or more-disc spaces, changes in the normal curvature of the spine, formation of osteophytes, sclerosis of parts of the vertebrae adjacent to the damaged discs ${ }^{11}$. The development of osteophytes may cause compression of nerve roots resulting in the development of radiculopathy which produces neck pain that radiates in the distribution of the affected nerve root $^{2}$. While both spinal cord (neural) and vascular compressions are responsible for the myelopathic symptoms ${ }^{12}$.

Ibn Sīnā categorized the etiology of waja'ul mafāṣil into two types which is implemented on waja'ur raqaba also

1. Asbāb-i-fa'ilah (primary causes)

2. Asbāb-i-munfa'ilah (secondary causes)

\section{Asbāb-i-fa'ilah (Primary causes)}

Asbāb-i-fa'ilah includes Su-i-mizāj (deviated temperament) and mawād-i-fāsida (morbid matters). 


\section{Su-i-mizāj (Deviated temperament)}

Deviation in the temperament may be general (entire body) or local (a particular region). Different types of kaifìāt (qualities) act in different ways such as harārat as a multahib (inflammatory), Burūdat as a mubarrid (refrigerant), and munjamid (consolidant), yabūsat as a munqabid (astringent). These temperamental deviations aggravate when rutūbāt-i-gharība (abnormal fluids) are involved ${ }^{8}$.

\section{Mawād-i-Fāsida (Morbid matters)}

The morbid matter may be dam-i-khāliṣ (pure blood), dam-ibalghamī (phlegmatic blood), dam-i-șafrāwī (bilious blood), dam-i-ṣaudāwī (melancholic blood), balgham-i- khāliṣ (pure phlegm), sudda-i-balgham-i-khām (obstruent of raw phlegm), Mirrahe khāliṣ (pure bilious), Balgham and Mirrah ka murakkab (phlegmatic bilious), Midda (pus), Riyāh (flatulence). It is usually caused by the quantitative or qualitative disproportion of Khilt-iBalgham (phlegmatic humour) then Balgham-i-Khām (raw phlegm), then Khilt-i-dam (sanguine humour), then Khilt-i-șafra (bilious humour) and rarely due to Saudā (black bile) $)^{8,13}$.

\section{Asbab-i- munfa'ilah (Secondary causes)}

These causes indirectly affect the joints and make the joint susceptible to accept the morbid material and cause structural as well as functional disturbance in the joints such as:

- Widening of Majra-i-tabaiya (natural passage) due to congenital and acquired causes

- Formation of new unnatural passage due to movement

- An increased movement produces more heat in the joint ${ }^{8}$

The pathogenesis of cervical spondylosis involves a degenerative cascade that produces biomechanical changes in the cervical spine, manifesting as secondary compression of neural and vascular structures ${ }^{14}$. Degenerative changes begin with intervertebral disc desiccation, which is associated with an increase in the ratio of keratin sulfate to chondroitin sulfate. An increase in the keratin-chondroitin ratio prompts changes to the proteoglycan matrix resulting in loss of water, protein, and mucopolysaccharides within the intervertebral disc. Desiccation of the disc causes the nucleus pulposus to lose its elasticity as it shrinks and becomes more fibrous. As the nucleus pulposus loses its ability to maintain weight-bearing loads effectively, it begins to herniate through the fibres of the annulus fibrosus and contributes to the loss of disc height, ligamentous laxity and buckling, and compression of the cervical spine. With further disc desiccation, the annular fibres become more mechanically compromised under compressive loads, producing significant alterations in the load distribution along the cervical spine. The result is a reversal of the normal cervical lordosis. Progression of the kyphosis causes the annular and Sharpey's fibres to peel off from the vertebral body edges, resulting in reactive bone formation $^{12,14,15}$. These pathological changes occur most frequently at the C5-C6 and C6-C7 levels as most of the sub axial flexion-extension movement occurs at these levels ${ }^{15}$.

Sihat (health) lasts when the akhlāt (humours) are in "etedali kaifiyat" (equilibrium) and disease occurs due to disequilibrium among akhlāt. This is the basis of the pathology of the disease ${ }^{16}$. Zakaria Rāzì said that the first and foremost cause of waja'ul mafășil lies in the abnormal formation of chyme, and this abnormal chyme produces abnormal akhlāt particularly Ghayr Țaba't Balgham (abnormal phlegm). This Ghayr Țaba't Balgham (abnormal phlegm) gets accumulated in the joints of the body causing swelling, tenderness, and pain. Waja'ul-
Mafāṣil clinically resembles osteoarthritis. When these changes occur in Fiqrāte 'Unuq (cervical vertebrae), they cause Waja'ur Raqaba (cervical spondylosis) ${ }^{17}$.

\section{CLINICAL FEATURES}

An individual with degenerative change in the cervical spine may be asymptomatic or can present as pure axial neck pain, cervical radiculopathy, cervical myelopathy, or cervical myeloradiculopathy ${ }^{18}$.

\section{Axial neck pain}

1. Stiffness and pain in the cervical spine are the common complaints that are more severe in the upright position and relieved with bed rest. Neck motion, especially in hyperextension and side-bending, or by activities in which the neck is held in the same position for a prolonged period, typically increases the pain ${ }^{14}$.

2. In upper cervical spine diseases, patients may report radiating pain into the back of the ear or occiput while in the diseases of the lower cervical spine, patients may report radiating pain into the superior trapezius or periscapular musculature.

3. Jaw pain or chest pain may also be associated as an atypical symptom with cervical spondylosis, occasionally ${ }^{14}$.

\section{Cervical radiculopathy}

Cervical radiculopathy is caused by the compression of one or more nerve roots ${ }^{11}$.

1. Radicular symptoms can present as unilateral or bilateral neck pain, arm pain, scapular pain, paresthesia, and arm or hand weakness.

2. Pain is exacerbated by a head tilt, hyper-extension, and sidebending towards the affected side ${ }^{14}$.

\section{Cervical myelopathy}

Cervical myelopathy is a condition caused by the compression of the spinal cord ${ }^{19}$. Cervical spondylosis is the most common nontraumatic cause of myelopathy in the cervical spine ${ }^{20}$.

- It can initially be presented with hand weakness and clumsiness, resulting in the inability to complete tasks requiring fine motor coordination (e.g., buttoning a shirt, tying shoelaces, picking up small objects).

- Gait instability and unexplained falls are reported with cervical myelopathy.

- Urinary symptoms (i.e., incontinence) are rare and typically appear late in disease progression ${ }^{14}$.

Description of clinical features of Waja'ul Mafāṣil present in the classical textbooks of Unānī medicine is based on causative factors in the case of Sū-i-Mizāj Sāda

- The onset of pain is gradual

- No change in skin colour

- Pain without heaviness, inflammation or swelling in case of Riyāh

- $\quad$ Pain with tension

- Pain is shifting in nature

- Absence of heaviness but severe distension in the case of Khiltī Mādda

- $\quad$ Sudden onset of disease

- $\quad$ Pain with heaviness

- change in skin colour 
- $\quad$ Presence of marked swelling or inflammation ${ }^{7}$

\section{MANAGEMENT}

Cervical spondylosis is managed by pharmacological, nonpharmacological and surgical intervention depending on the condition and severity of the case ${ }^{11}$. Non-pharmacological management includes manual therapy, hot packs, exercise therapy, strength training, endurance training, and stretching, massage, short wave diathermy, transcutaneous electrical nerve stimulation, ultrasound, interferential therapy, and infra-red radiations, etc ${ }^{21}$. Pharmacological intervention includes nonsteroidal anti-inflammatory drugs, muscle relaxants, opioid analgesics, corticosteroids, and anti-emetics ${ }^{22,23}$. Surgical intervention should be considered in patients with severe or progressive cervical myelopathy, or cervical radiculopathy following the failure of non-operative measures ${ }^{14}$. The use of analgesics provides significant relief in symptoms of cervical spondylosis for a very short time, but their prolonged use may induce several adverse effects ${ }^{24}$.

\section{Unānī treatment}

Waja'ur Raqaba is treated on the same line of treatment as waja'ul mafāșil. The line of treatment, to restore and normalize the Sū-iMizāj, Unānī physicians described Ușūl-i-'Ilāj in the same manner according to causative factors those produce pain in cervical region ${ }^{17,25}$

This can be done by any one of these three treatment modalities viz., 'Ilāj bit-Tadbīr (Regimenal therapy), 'Ilāj bid-Dawā' (pharmacotherapy) and Ilāj bi'l-Yad (surgical therapy). It does not mean that the use of these three methods is mandatory in every treatment simultaneously, but it means that no fourth method is required, and the aim of treatment is achieved only by one or two or all these three accordingly ${ }^{26,27}$.

\section{'Ilāj bit-Tadbīr (regimenal therapy)}

Lots of claims and evidence for the effectiveness of several Regimenal modalities in the management of cervical spondylosis are available. Different types of regimes are claimed beneficial for musculoskeletal disorders viz; dalk (massage therapy), riyazat (exercise). nutool (douching), abzan (sitz bath), takmeed (fomentation), hammam (Turkish bath), Hijāma (cupping) ${ }^{28-30}$.

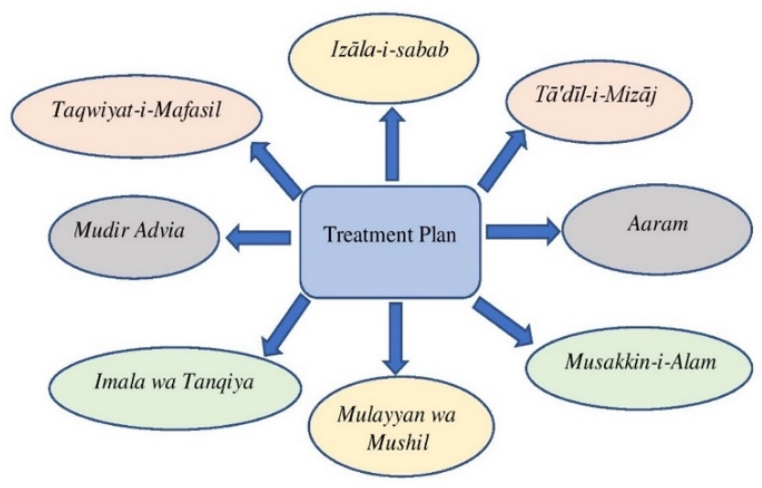

Figure 1: Schematic presentation of Usūl-i-'Ilaj (line of treatment)

\section{Dalk (Massage)}

Dalk is one of the very important Regimenal modalities of Ilāj
bit-Tadbīr for various neurological and musculoskeletal disorders $^{31}$. Pressure, friction, and manipulation of tissues are applied in $i^{32}$. According to Ibn-i-Rushd, Dalk is a type of exercise and used to remove waste metabolites of digestion (Hazme Uzwi/hazme akheer) ${ }^{33}$. The mechanism of action of Dalk is based on the holistic approach of two fundamental concepts i.e., Tanqia-i-Mawād (evacuation of morbid humour) and Imāla-iMawād (diversion of humour). Tanqia-i- Mawād means the resolution and excretion of morbid humours and excessive fluids from the body, hence preserving the homeostasis in the quality and quantity of four bodily humours, responsible for the maintenance of normal health. Imāla-i-Mawād refers to the diversion of the morbid matter from the site of the affected organ to the site where it can be easily evacuated from the body tissues. It also causes sedation, analgesia and increases blood circulation $^{33,34}$. It has various types or varieties. Dalk-I-Laiyyan (gentle massage) with roghan-i-gul-i-ākh is found veryeffective in treating cervical spondylosis. Dalk with roghan-i-shibbat, roghan-i-bāboona and roghan-i- murakkab are also effective in various joint disorders. A massage with roghan-i-nargis or roghan-i-sosan mixed in roghan-i-dhatura is effective if the pain is associated with barūdat (cold). If pain is associated with additional harārat (heat), a massage with roghan-e-hina is useful $^{33}$. Duration of massage at affected area should be prolonged according to the therapeutic purposes ${ }^{32,33}$.

Lone AH et al. concluded that massage may be used effectively in various disorders especially musculoskeletal and nervous disorders where medical treatment is of less value ${ }^{35,36}$. Tanwir $e t$ $a l$. suggested that dill seed oil is very effective and safe in relieving and halting the progress of neck pain and associated symptoms $^{37}$.

\section{Ḥijāma (Cupping)}

Hijāma is an Arabic word which technically means the application of cups and the literal meaning of Hijāma is sucking ${ }^{38,39}$. Jālinūs has mentioned that in cases of the accumulation of thick humours in the joint, Hijāma is very useful $^{40,41}$. It is a technique carried out by application of cup on the body surface by creating vacuum either through heat or by special suction apparatus for evacuation of the morbid materials, diversion of the material from the diseased part and to encourage the blood flow to the affected site $e^{40,42,43,44}$.

Based on scarification Hijāma has been classified into two main types.

1. Hijāma bilā-Shart (dry cupping)

2. Hijāma bish-Shart (wet cupping) ${ }^{45}$

Cupping therapy works in two ways

1. Tanqiya-i-Mawād (Evacuation of morbid matter)

2. Imāla-i-Mawād (Diversion of morbid matter)

Hijāma bila Shart works on the principle of Imāla-i-Mavād (diversion of morbid matter) and causes the diversion of morbid matter from one site to another ${ }^{46}$.

Hijāma bish Shart works on the principle of Tanqiya-i-Mavād (evacuation of morbid matter) and evacuates the morbid matter from the body ${ }^{47-49}$. Kim TH et al. reported the efficacy of cupping therapy and an exercise program in reducing the pain and improving the neck function among the participants in study ${ }^{50}$. The effectiveness of wet cupping therapy in non-specific neck and shoulder pain was reported by Arslan et al.,${ }^{51}$. Lauche $\mathrm{R}$ et al. concluded that significant increases were found after cupping 
therapy in physical functions and quality of life in the patients with chronic nonspecific neck pain and suggested that cupping treatment might have sustainable effects for up to 2 years ${ }^{52}$. Similarly, Wen MX et al., concluded that wet cupping therapy provides a rapid therapeutic effect in nerve-root type cervical spondylosis, thus exhibiting significant analgesic effects ${ }^{53}$.

\section{Faṣd (Venesection)}

Faṣd is one of the classical Regimenal procedures in the Unānī system of medicine in which a small incision with knife or scalpel is given to the superficial vessel containing Mawad-i-fasida (morbid material). It is a general method of diversion and evacuation of morbid humour from the body presented in the blood vessels. This diversion or evacuation is very important for the restoration and preservation of health. It also helps in relieving inflammatory congestion and pain in Waja'ul Mafāșil ${ }^{54-57}$. Mou MY et al., reported that bloodletting and cupping share a similar effect with acupuncture in relieving pain relief and improving the quality of life in patients with cervical radiculopathy ${ }^{58}$. Similarly, Guimei $\mathrm{J}$ et al. claimed the analgesic effect of bloodletting therapy at local myofascial trigger points. Clinically, bloodletting and acupuncture therapy had the same efficacy as the lidocaine block therapy, with fewer adverse reactions ${ }^{59}$.

\section{Irsal-i-alaq (Leech therapy)}

Leech therapy works on the principle of bloodletting. It is a bloodsucking process in which medicinal leeches are applied usually on the affected parts of the body for tanqiya-i-mavād ${ }^{60}$. Scientific studies have revealed that the anti-coagulant substances, such as hirudin, calin, histamine-like vasodilators, collagenase, hyaluronidase etc. present in the saliva of leeches, are responsible for various pharmacological actions ${ }^{53}$. Application of medicinal leeches is a commonly practiced procedure in Regimenal therapy to treat various disorders including the pain of musculoskeletal origin $^{56}$. Stange R et al. concluded that leech therapy significantly improves pain and functional symptoms of patients with osteoarthritis of the knee compared to a sham therapy ${ }^{61}$. Similarly, Hohmann CD et al., concluded that a single session of leech therapy is effective in lowering the intensity of pain for the short term and in improving physical function and quality of life over the intermediate term (4 weeks and 8 weeks, respectively) ${ }^{62}$.

\section{Takmīd (Fomentation)}

Takmīd is a therapeutic procedure of application of hār (hot) or bārid (cold) material over the body for therapeutic purposes. It has several therapeutic effects such as pain alleviation, muscle spasms relaxation, improvement in circulation, reduction in inflammation and improvement in the absorptive process from the body surface, promotion of perspiration, stimulation or inhibition of the cutaneous nerve endings according to applied temperature45,56. Cramer $\mathrm{H}$ et al. concluded that self-treatment with thermotherapy seems to be effective in relieving pain and improving sensory functioning in patients with chronic mechanical neck pain ${ }^{63}$.

\section{Dimād / Tila (Ointment / Liniment)}

Dimād (ointment) is a topical medication that is applied to the body surface for therapeutic purposes. It is a semisolid form of medicine prepared from the powder of crude drugs $\mathrm{s}^{45,56}$.

Tila (liniment) is a medicated topical preparation for application to the skin surface. It has a lesser viscosity than lotions and is usually rubbed over the $\operatorname{skin}^{45,56}$.
Both Dimād and Țila has significant use in Regimenal therapy and are used for therapeutic purposes such as inflammation, swelling, sedation and anesthesia, dissolution, and diversion of morbid materials from congested area $\mathrm{a}^{45,56}$.

\section{Ḥammām (Turkish Bath)}

In the Unānī system of medication, the term hammām refers to hot bath ${ }^{64}$. A temperature of $37-40^{\circ} \mathrm{C}$ for $10-15$ minutes followed by rest for an hour is beneficial ${ }^{32,65}$. This regimen opens the skin pores and evacuates the causative waste from the body in the form of sweat and vapours ${ }^{54,64}$. It is a structure of three-rooms, located at progressively higher temperatures started from Bārid Ratab (cold \& moist) room then Hār Ratab (hot \& moist) room and finally Hār Yābis (hot \& dry) room ${ }^{56,64}$. This therapy relaxes the muscle, relieves the tension that has built up and thus, alleviates pain consequently ${ }^{66}$. It is evident that hammām is not only an instrument for cleaning the body, but it also has various therapeutic effects ${ }^{67}$. Karagulle $\mathrm{M}$ et al. concluded that hammām session caused a significant decrease in mean bodily pain score and a significant improvement in psychological scores ${ }^{64}$.

\section{Nutūl (Irrigation)}

Nutūl is a procedure of continuous pouring or dripping of medicated oil or decoction or infusion of herbs over different parts of the body surface from pre-fixed height for a fixed period $^{45,56}$. It can be classified into Nutūl Hāar (hot irrigation) and Nutūl Bārid (cold irrigation) ${ }^{32}$. Ibn-i-Sīnā states that Nutūl is the best treatment for the resolution of inflammation or altered body temperament ${ }^{44}$. Nutūl Hāar is mainly used in inflammatory conditions as an anti-inflammatory modality ${ }^{68,69}$.

\section{Riyāḍat (Exercise)}

In the Unānī system of medicine, exercise is one of the methods of treatment of Regimenal therapy and is used as a voluntary movement with the purpose of tanqiya-i-mavād (evacuation of morbid material), and for purification of the body in an individual. It maintains good health and prevents or cures diseases as well ${ }^{70}$. It strengthens the muscles, joints, nerves, and ligaments. Exercise of the neck like flexion, extension, side flexion, right and left rotation is beneficial in cervical spine symptoms including headache, dizziness, nausea, vertigo etc. The increased flow of blood at the affected region improves the movements and prevents spasms which ultimately relieves pain. Exercise causes endorphin production which gives a feeling of wellbeing and the body's threshold against pain also increases ${ }^{32}$. Chiu TT et al. reported that after a 6 weeks' training program, patients in the exercise group improved significantly in disability scores, subjective report of pain, isometric neck muscle strength, and satisfaction $^{71}$.

\section{CONCLUSION}

In the view of Unānī perspective, it can be concluded that ' ilāj bit-tadbīr (Regimenal therapy) is an effective method of treatment for the management of waja'ur raqaba (cervical spondylosis). Regimenal therapy is one of the important modes of Unāni treatment which plays a pivotal role in the health care system. Several regimens such as Dalk (massage), Hijāma (cupping), Faṣd (venesection), Irsāl-i-'alaq (leech therapy), Takmīd (fomentation), Ḥammām (Turkish bath), Dimād / Tila (Ointment / Liniment) and Riyādat (exercise), etc. have been recommended by Unānī physicians for the treatment of waja'ur raqaba. Some Regimenal modalities are richly evidenced for their effectiveness against various musculoskeletal conditions. But others need to be evaluated scientifically for their efficacy in 
cervical spondylosis and other joint disorders. Detailed studies regarding the mechanism of action and well-designed standard operating procedures of Regimenal procedures, supported by scientific studies to open new therapeutic avenues, and worldwide acceptance would help in the safe and efficient application of these regimens.

\section{REFERENCES}

1. Venes D, Editor. Taber's Encyclopedic Medical Dictionary Vol 1 \& 2. $20^{\text {th }}$ ed. New Delhi: F.A. Davis Company Philadelphia; 2006.

2. Colledge NR, Walker BR, Ralston SH. Davidson's Principles and of Practice of Medicine. 21 $1^{\text {st }}$ ed. USA: Churchill Livingstone; 2002.

3. Reddy RS, Maiya GA, Rao SK. Proprioceptive reposition errors in subjects with cervical spondylosis. IJHSR 2012; 1(2): 65-73.

4. Binder A I. Cervical spondylosis and neck pain. BMJ. 2007; 334(7592): 527-31. DOI: $10.1136 / \mathrm{bmj} .39127 .608299 .80$

5. Holly LT, Wang C, Woodworth DC, Salamon N, Ellingson BM. Neck disability in patientswith cervical spondylosis is associated with altered brain functional connectivity. J. Clin. Neurosci 2019; 69: 149-54. DOI: 10.1016/j.jocn.2019. 08.008 .

6. Theodore N. Degenerative cervical spondylosis. N Engl J Med 2020; 383(2): 159-68. DOI: 10.1056/NEJMra2003558.

7. Khan M A. Akseer-e-Azam (Urdu Translation by Hkm. Mohd Kabeeruddin). New Delhi: Idara Kitab-ush-Shifa; 2011.

8. Sina I. Al-Qanoon Fit Tib. Vol. I \& III. (Urdu translation by GH Kantoori). New Delhi: Idara Kitab-ush-Shifa; 2010.

9. Mohammad Shahid Khan, S. Javed Ali, Mohd Nayab, Abdul Aziz. Effect of Massage with Roghan Biskhapra (Oil of Trianthema portulacastrum L.) in Rheumatoid Arthritis: Case Reports of Two Patients. RRJoHS 2015; 4(3): 1-3.

10. Ferrara LA. The biomechanics of cervical spondylosis. Adv. Orthop; 2012. p. 1-5. doi:10.1155/2012/493605.

11. Golwalla AF, Golwalla SA, Nadker MY. Golwalla's Medicine for Students. $25^{\text {th }}$ Ed. New Delhi: Jaypee Brothers Medical Publisher; 2017.

12. Mullin J, Shedid D, Benzel E. Overview of cervical spondylosis pathophysiology and biomechanics. World spinal column J 2011; 2(3): 89-97.

13. Mohd Nayab, Mohd Anwar, Tanzeel Ahmad. Effect of Hijamat bila Shurt in the Management of Waja-ul-Mafasil A clinical Study. Hippocratic Journal of Unani Medicine 2009; 4(3): 1-7.

14. Kuo DT, Tadi P. Cervical Spondylosis. [Updated 2021 May 9]. In: Stat Pearls [Internet]. Treasure Island (FL): Stat Pearls Publishing; 2021 Jan-. Available from: https://www.ncbi. nlm.nih.gov/books/NBK551557/

15. Takagi I, Eliyas JK, Stadlan N. Cervical spondylosis: an update on pathophysiology, clinical manifestation, and management strategies. Dis Mon 2011; 57(10): 583- 91. DOI: 10.1016/j.disamonth.2011.08.024

16. Majoosi A. Kaamilus Sana'ah. Vol. $1^{\text {st }}$ (Urdu translation by GH Kantoori). New Delhi: Idara Kitab-ush-Shifa; 2010.

17. Razi Z. Kitabul Hawi. Vol. XI. New Delhi: Central Council for Research of Unani Medicine, Ministry of Health and FamilyWelfare, Govt. of India; 2004.

18. Que Q, Ye X, Su Q, Weng Y, Chu J, Mei L, et al. Effectiveness of acupuncture intervention for neck pain caused by cervical spondylosis: study protocol for a randomized controlled trial. Trials 2013; 14(1): 1-7. doi:10.1186/1745-6215-14-186

19. William NS, Bullstrode CJK, Conell PRO. Bailey \& Love's Short Practice of Surgery. $25^{\text {th }}$ ed. London: Edward Arnold
Publishers Ltd; 2008

20. Mattei TA, Goulart CR, Milano JB, Dutra LP, Fasset DR. Cervical spondylotic myelopathy: pathophysiology, diagnosis, and surgical techniques. ISRN Neurol 2011; 2011: 463729. doi:10.5402/2011/463729

21. Harsulkar SG, Khatri SM, Rao K, Iyer C. Effectiveness of Gong's mobilization in cervicalspondylosis: A prospective comparative study. Int J Community Med Public Health 2015; 2(1): 38-44. DOI: 10.5455/2394-6040.ijcmph 20150209.

22. Hirpara KM, Butler JS, Dolan RT, O'Byrne JM, Poynton AR. Non-operative modalities to treat symptomatic cervical spondylosis. Adv. Orthop 2012; 2012: 1-5. doi: $10.1155 / 2012 / 294857$

23. Maheshwari J, Mhaskar VA. Essential of Orthopedics. $4^{\text {th }}$ ed. New Delhi: Jaypee Brothers; 2011.

24. Miao Q, Qiang JH, Jin YL. Effectiveness of percutaneous neuromuscular electrical stimulation for neck pain relief in patients with cervical spondylosis. Medicine 2018; 97(26): 14. doi:10.1097/MD.0000000000011080.

25. Arzani A. Tibb-e-Akbar (Urdu Translation by Hkm. M Hussain). Deoband: Faisal Publication; YNM.

26. Nafeesi B. Tarjuma wa Sharae Kulliyate Nafeesi (Urdu translation by M Kabeeruddin). New Delhi: Idara Kitab-ushShifa; 1954

27. Mohd Nayab, Abdul Nasir Ansari, Fatima Khan. A Panoramic View of most commonly used Regimenal Modalities (Tadabeer) for Joint Pain in Unani System of Medicine: A Critical Review. J. drug deliv. ther 2021; 11(2): 228-231. DOI: http://dx.doi.org/10.22270/jddt.v11i2.4561.

28. Md. Anzar Alam, Mohd. Nayab, Abdul Azeez, Mohd. Aleemuddin Quamri, Abdul Nasir Ansari, Muscular Dystrophy (Istirkha) and its management through Unani Medicine: A Review, Int. J. Herb. Med 2014; 2(4): 01-04.

29. Mohd Nayab. Ābzan (Sitz Bath)-An effective mode of treatment in 'Ilaj bit Tadbīr (Regimenal Therapy). The Pharma Innovation Journal (International) 2016; 5(12): 4549.

30. Izhar Ahmad, Mohd Nayab, Tanzeel Ahmad. Effect of gliding cupping with Roghan-e-Surkh in low backache (Waja-uz-Zahr): a case series study. Drug Metab Pers Ther. 26 March - 2021. DOI: https://doi.org/10.1515/dmpt-20200177.

31. Ansari A, Nayab M, Ansari AN, Saleem S. An Analytical Review on Ancient Regimen: Dalk (Massage) Therapy in Unani System of Medicine. Int. J. Res. Anal. Rev 2020; 7(2): 872-878.

32. Ameen F. Role of Ilaj-Bit-Tadbeer (Regimenal Therapy) in the Management of Waja-ul-Unq (Cervical Spondylosis): A Review with Unani Perspective. Int J Adv Res (Indore) 2020; 8(4): 307-11. DOI: 10.21474/IJAR01/10781

33. Ahmed K, Jahan N, Aslam M, Kausar H, Khalid M, Ali H. Dalak (massage) in Unani medicine: a review. J. adv. res. Ayurveda, Yoga, Unani, Siddha Homeopathy 2014;3(1): 16274.

34. Bhat MD, Ansari MI, Malik R. Dalk (Massage) in Unani Medicine: An Ancient Regimen for Preventive and Rehabilitative Treatment of Various Diseases. RRJoUSH 2017; 4(1): 19-27.

35. Lone AH, Ahmad T, Anwar M, Akhtar MS. Role of Massage Therapy in the Management and Prevention of Diseases-A Case series of Medicated Massage. Int J Res Ayurveda Pharm 2012; 3(06): 1474-77.

36. Meraj Ul Islam, Mohd Nayab, Abdul Nasir Ansari. Effect of dry cupping versus soft and prolonged massage in the management of knee osteoarthritis - A randomized controlled clinical trial. J. Complement. Integr. Med. Published online on 31 March 2021. DOI: https://doi.org/10.1515/jcim-2020- 
0350

37. Alam MT, Zulkifle M, Ansari AH, Sherwani AM, Perveen A. Relieving and Halting the Progress of Cervical pain by Therapeutic Oil: A Secondary Prevention. Int. Res. J. Medical Sci 2013; 1(9): 1-5.

38. Dar AK, Lone AH. Therapeutic application of Al Hijamah (cupping therapy) in osteoarthritis of the knee. Int. J. Res. Dev. Pharm. Life Sci 2015; 4(3): 1540-44.

39. Sultana A, Rahman K. Hijamat (cupping therapy) and gynecological diseases - a review. Journal of the International Society for the History of Islamic Medicine; 2012. p. 127-35.

40. Qamri AMH, Minhaj ul Ilaj (Urdu Translation of Ghina Muna) New Delhi: Central Council for Research in Unani Medicine; 2008.

41. Hina V Kouser, Mohd Nayab, Ayesha Tehseen, Shaista Mahfooz, Baig Ruqaiyya, Mohd Anwar. Evidence-Based Therapeutic Benefits of Cupping Therapy (Hijāma): A Comprehensive Review. J. drug deliv. ther. 2021; 11(4-S): 258-262. DOI: http://dx.doi.org/10.22270/jddt.v11i4-S.4969

42. Anjum N, Jamil S, Hannan A, Akhtar J, Ahmad B. Clinical efficacy of Hijamat (cupping) inWaja-ul-Mafasil (Arthritis). Indian J. Tradit. Knowl. 2005; 4(4): 412-15

43. Tagil SM, Celik HT, Ciftci S, Kazanci FH, Arslan M, Erdamar $\mathrm{N}$, et al. Wet-cupping removes oxidants and decreases oxidative stress. Complement Ther Clin Pract 2014; 22 (6): 1032-36. DOI: 10.1016/j.ctim.2014.10.008.

44. Mahboob Ali, Abdul Nasir Ansari, Mohd Nayab, Hina Ansari, Shabnam Ansari. Efficacy of a poly-herbal Unani formulation and dry cupping in treatment of post-stroke hemiplegia: An exploratory, single-arm clinical trial. Adv Integr Med; 2020. https://doi.org/10.1016/j.aimed. 2020.11.001

45. Hamid A. Ilaj-bil-tadbeer (Regimenal therapy): A noble method of treatment in Unani medicine: A Review. International Journal of Medicine Research 2018; 3(3): 1-6.

46. Mohd Nayab, Abuzar Lari. Efficacy of Hijamat-bila-Shart (Dry Cupping) in the Management of Waja-uz-Zahr (Low Back Pain): An Open Randomized Controlled Clinical Trial. Int. J. Herb. Med 2018; 6(1): 16-19.

47. Lari A, Nayab M, Tausif M, Lari J, Alam A. Therapeutic potentials of hijama-bila-shart (dry cupping therapy): A review. Int. J. Unani integr. Medicine 2017; 1(1): 21-24.

48. Nayab M, Anwar M, Qamri MA. Clinical study on Waja-ulMafasil and evaluation of the efficacy of Hijamat-Bila-Shurt in the treatment. Indian J. Tradit. Knowl 2011; 10(4): 697701.

49. Mohammad SH, Fasihuzzaman AJ, Siddiqui MA. Unani Concept and Management of Waja-Ul-Mafasil (Arthritis) with Special Reference to Hijamah (Cupping Therapy). Indo Am. J. Pharm 2014; 4(2): 1098-103.

50. Kim TH, Kang JW, Kim KH, Lee MH, Kim JE, Kim JH et al. Cupping for treating neck pain in video display terminal (VDT) users: a randomized controlled pilot trial. J Occup Health 2012; 54(6): 416-26.

51. Arslan M, Gökgöz N, Dane Ş. The effect of traditional wet cupping on shoulder pain and neck pain: A pilot study. Complement. Ther. Clin. Pract. 2016; 23: 30-3. DOI: 10.1016/j.ctcp.2016.02.003.

52. Lauche R, Cramer H, Langhorst J, Dobos G. Cupping for chronic nonspecific neck pain: a 2-year follow-up. Complement. Med. Res 2013; 20(5): 328-33. DOI: 10.1159/000355634.

53. Wen MX, Ying W, Sheng-ai P, Wen-tao LV, Cheng-hui ZH, Ming-yuan MU et al. Wet cupping therapy improves local blood perfusion and analgesic effects in patients with nerveroot type cervical spondylosis. Chin. J. Integr. Med 2018; 24(11): 830-4. DOI: 10.1007/s11655-017-2925-7.

54. Ansari AP. 'Ilāj bi'l-Tadbīr (Regimenal therapy): A core mode of Unani treatment. J. Complement. Integr. Med 2020; 1-10. DOI: $10.1515 / \mathrm{jcim}-2020-0048$.

55. Ashraf R, Mohi-ud-din R. Unani aspect of arthritis (Waja-ulMafasil) \& its management: A review. Int. J. Herb. Med. 2018; 6(3): 12-19.

56. Islam MU, Nayab M. An Overview of Waja-ur-Rukbah (Knee Osteoarthritis) with Reference to Waja-ul-Mafasil and its Regimenal Management (Ilaj bit tadbeer) in Unani System of Medicine. Asian Journal of Traditional, Complementary and Alternative Medicine 2021; 4 (1-2): 19-29. doi:10.22040/ATCAM.2021.242486. 1008

57. S Javed Ali, Mohd Nayab, Barkati Mohammad Tarique. Effect of Fasd (Venesection) in the Management of acute cases of Irqunnisa (Sciatica) - A case Series Study. RRJoHS 2016; 5(1): 17-21.

58. Mou MY, Piao SA, Meng XW, Guo Y, Chen ZL, Zhu CH et al. Therapeutic efficacy observation on bloodletting and cupping for cervical radiculopathy. J. Acupunct. Tuina Sci 2015; 13(4): 236-41. doi:10.1007/s11726-015-0859-1.

59. Guimei J, Chao J, Mode L. Effect of bloodletting therapy at local myofascial trigger points and acupuncture at Jiaji (EXB 2) points on upper back myofascial pain syndrome: a randomized controlled trial. J. Tradit. Chin. Med 2016; 36(1): 26-31.

60. Khalique A, Siddiqui MY, Ashraf MA. Irsal-e-Alaq (Hirudotherapy) in Unani system of medicine and modern medicine an overview. Int. J. Unani. Integ. Med 2019; 3(1): 1-6.

61. Stange R, Moser C, Hopfenmueller W, Mansmann U, Buehring M, Uehleke B. Randomized controlled trial with medical leeches for osteoarthritis of the knee. Complementary therapies in medicine 2012; 20(1-2): 1-7. DOI: $10.1016 /$ j.ctim.2011.10.006.

62. Hohmann CD, Stange R, Steckhan N, Robens S, Ostermann $\mathrm{T}$, Paetow A et al. The Effectiveness of Leech Therapy in Chronic Low Back Pain: A Randomized Controlled Trial. Dtsch Arztebl Int 2018; 115(47): 785-92. DOI: 10.3238/arztebl.2018.0785.

63. Cramer H, Baumgarten C, Choi KE, Lauche R, Saha FJ, Musial $\mathrm{F}$, et al. Thermotherapy self-treatment for neck pain relief $-\mathrm{a}$ randomized controlled trial. Eur. J. Integr. Med 2012; 4(4): 371-78. DOI: 10.1016/j.eujim. 2012.04.001.

64. Mazhar SA, Anjum R, Anwar AI, Khan AA. Hammam Therapy: An Ancient Wisdom with Contemporary Relevance. J. integr. community health 2020; 9(1): 25-30.

65. Jabeen A, Mansoori SA, Jilani S, Azam R. Management of cervical spondylosis in Unani system of medicine. The Pharma Innovation International Journal 2018; 7(10): 655-60.

66. Karagulle M, Nagy G, Barna I, Barut Y, Issever H, Karagulle $\mathrm{MZ}$ et al. An observation on health effects of hamam (turkish bath). Presse Therm Clim 2011; 148: 79-86.

67. Mohammad Zaki Ahmad, Abdul Nasir Ansari, Mohd Nayab. Efficacy of Hammām-i-yābis (dry bath) in Metabolic Syndrome: A single-arm, open-labelled clinical trial. J. Complement. Integr. Med. Published online on 16 July 2021. DOI: https://doi.org/10.1515/jcim-2021-0072

68. Azam R, Mushtaq S, Fassihuzaman JA, Zaidi Z, Alam S. Nutool (Irrigation)- an effective mode of treatment in Ilaj bit Tadbeer (Regimenal therapy). Indo Am. J. Pharm 2014; 4(12): 5787-91.

69. Mohd Nayab, Fatima Khan, Abdul Nasir Ansari, Tariq Nadeem Khan, Malik Itrat, Nutūl as an effective and time tested Regimenal modality in Unani system of medicine - An Overview. J. drug deliv. ther 2021; 11(3): 132-137. DOI: http://dx.doi.org/10.22270/jddt.v11i3.4716

70. Farooqui Y, Siddiqui MY, Zehra A, Zafar M. Role of Riyazat in prevention and control of lifestyle diseases: A Review. J. drug deliv. ther 2020; 10(1-s): 211-14. DOI: 
Hina Kouser V et al / Int. J. Res. Ayurveda Pharm. 12 (5), 2021

10.22270/jddt.v10i1-s.3929.

71. Chiu TT, Lam TH, Hedley AJ. A randomized controlled trial on the efficacy of exercise for patients with chronic neck pain. Spine 2005; 30(1): E1-7. PMID: 15626966.

\section{Cite this article as:}

Hina Kouser $\mathrm{V}$ et al. Regimenal modalities for the management of cervical spondylosis (Waja' Ur Raqaba): An evidence-based comprehensive review. Int. J. Res. Ayurveda Pharm. 2021;12(5):79-85 http://dx.doi.org/10.7897/2277-4343.1205150

\section{Source of support: Nil, Conflict of interest: None Declared}

Disclaimer: IJRAP is solely owned by Moksha Publishing House - A non-profit publishing house, dedicated to publishing quality research, while every effort has been taken to verify the accuracy of the content published in our Journal. IJRAP cannot accept any responsibility or liability for the site content and articles published. The views expressed in articles by our contributing authors are not necessarily those of IJRAP editor or editorial board members. 